\title{
Analysis Of Fiber Content of Nuggets and Crackers With The Basic Ingredients of Kepok Banana Tuber (Musa Paradisiaca Var. Balbisina Colla)
}

\author{
Rifatul Ridlo ${ }^{1}$, Sugeng Maryanto ${ }^{2}$, Riva Mustika Anugrah ${ }^{3}$ \\ ${ }^{1,2,3}$ Nutrition Study Program, Faculty of Health Sciences, \\ Universitas Ngudi Waluyo \\ Email: sugengmaryanto99@gmail.com
}

\begin{abstract}
Nugget and crackers are fast foods that are widely consumed and favored by the public, usually used as dishes or snacks. Banana tubers is a local food commodities which contains of high fiber can be processed as an ingredients nuggets and crackers. The purpose ofthis reseach was to determine the fiber content of nuggets and crackers with the basic ingredients of kepok banana tubers (Musa paradisiaca Var. Balbisina Colla). This study was experimental design. The nugget formulation consisted of 3 comparisons, the ratio of banana tuber : wheat flour (25\%: 75\%) $(F 1),(50 \%: 50 \%)(F 2)$, and (75\%: 25\%) (F3). The cracker formulation consists of 3 comparisons, the ratios of banana tuber: tapioca flour (25\%: 75\%) (F1), (50\%: $50 \%)(F 2)$, and (75\%: 25\%) (F3). Test the fiber containt by the gravimatry method which is then described.The results in this study was analyzed of the fiber value of nuggets and crackers kepok banana tuber every (100g). The highest fiber content of nuggets was F3: 0.514g, F2: $0.322 \mathrm{~g}$ and F1: $0.186 \mathrm{~g}$. The highest fiber content of Kepok banana tuber crackers is F3: 0.861g, F2: 0.747g and F1: 0.727g. The fiber value of the kepok banana tuber crackers is higher than the kepok banana tuber nugget.
\end{abstract}

Keywords: Nugget, Crackers, Kepok Banana Tuber, Fiber.

\section{Analisis Kandungan Serat Nugget dan Kerupuk dengan Bahan Dasar Bonggol Pisang Kepok (Musa Paradisiaca Var. Balbisina Colla)}

\begin{abstract}
ABSTRAK
Nugget dan kerupuk merupakan makanan siap saji yang banyak dikonsumsi masyarakat, biasanya dijadikan sebagai lauk atau cemilan. Bonggol pisang merupakan komoditas pangan lokal tinggi serat yang dapat diolah menjadi nugget dan kerupuk. Tujuan dari penelitian ini adalah untuk mengetahui kandungan serat nugget dan kerupuk dengan bahan dasar bonggol pisang kepok. Penelitian ini merupakan penelitian experimental design. Penelitian ini merupakan penelitian experimental design. Formulasi nugget terdiri dari 3 yaitu, perbandingan bonggol pisang : tepung terigu $(25 \%: 75 \%)(\mathrm{F} 1),(50 \%: 50 \%)(\mathrm{F} 2)$, dan $(75 \%: 25 \%)(\mathrm{F} 3)$. Formulasi kerupuk terdiri dari 3 yaitu, perbandingan bonggol pisang : tepung tapioka $(25 \%: 75 \%)(\mathrm{F} 1),(50 \%: 50 \%)(\mathrm{F} 2)$, dan $(75 \%: 25 \%)(\mathrm{F} 3)$. Uji kandungan serat dengan metode gravimatri yang kemudian dideskripsikan. Hasil penelitian ini dianalisis nilai serat nugget dan kerupuk bonggol pisang kepok setiap (100g). Kandungan serat nugget tertinggi adalah F3: 0,514g , F2 : 0,322g dan F1: 0,186g. Kandungan serat kerupuk bonggol pisang kepok yang tertinggi adalah F3 : 0,861 g, F2 : 0,747g dan F1 : 0,727g. Nilai serat pada kerupuk bonggol pisang kepok lebih tinggi dari nugget bonggol pisang kepok.
\end{abstract}


Kata Kunci: Nugget, Kerupuk, Bonggol Pisang Kepok, Serat.

\section{PENDAHULUAN}

Produk pangan, terutama pangan lokal yang ada di Indonesia sangat beragam dan melimpah. Pangan lokal biasanya mempunyai hubungan dengan ciri khas, budaya atau adat istiadat masyarakat setempat. Jagung, sagu, singkong dan pisang merupakan salah satu contoh pangan tersebut. Produk pangan lokal harus dikembangkan terutama aspek kesehatan dan keamanan yang juga bersifat sebagai pangan fungsional. Pangan fungsional adalah pangan olahan yang mengandung satu atau lebih komponen pangan yang berdasarkan kajian ilmiah terbukti telah mempunyai fungsi fisiologis tertentu diluar fungsi dasarnya, tidak membahayakan dan dapat bermanfaat bagi kesehatan (BPOM, 2005). Pangan fungsional kaya akan komponen bioaktif yang bermanfaat bagi kesehatan, komponen bioaktif tersebut salah satunya adalah serat (Marsono, 2007).

Serat

(polisakarida, oligosakarida, dan lignin) merupakan bagian dari tumbuhan yang dapat dimakan atau analog karbohidrat yang tidak dapat dicerna dan diabsorpsi usus halus manusia dengan fermentasi lengkap atau sebagian pada usus besar. Konsumsi serat yang cukup dapat memberikan manfaat metabolik berupa pengendalian gula darah dan mampu mengatur kadar kolesterol dalam darah (American Association of Cereal Chemist, 2001). Manfaat serat menurut Marsono (2004) serat dapat menanggulangi masalah kesehatan diantaranya adalah diabetes melitus, hiperlipidemia dan penyakit saluran pencernaan.
Anjuran konsumsi serat adalah 20-35 gram/hari yang berasal dari berbagai sumber makanan (Perkeni, 2015). Salah satu jenis serat yaitu serat larut (pectin) bermanfaat sebagai antidiabetes (Maryanto dan Marsono, 2019). Sedangkan serat kasar dapat membantu mengurangi terjadinya obesitas (Santoso, 2011). Sumber serat dan pangan lokal diantaranya adalah sayur-sayuran, buah-buahan dan juga umbi-umbian.

Salah satu pangan lokal yang kaya akan serat terutama serat kasar adalah bonggol pisang. Bonggol pisang merupakan tanaman pisang yang berupa umbi batang atau batang aslinya (Satuhu dan Supriyadi, 2008). Dalam 100 gram bonggol pisang mentah atau basah mengandung protein 2,99 gram, lemak 0,96 gram dan serat 9,99 gram (Aswandi dkk., 2013). Pada penelitian Saragih (2014) varietas bonggol pisang yang terbaik adalah diperoleh dari varietas kepok. Bonggol pisang basah mengandung $43 \%$ kalori, $0,6 \%$ protein, $11,6 \%$ lemak, $15 \%$ hidrat arang, $60 \% \mathrm{Ca}$, $0,5 \% \mathrm{P}, 0,01 \% \mathrm{Fe}, 12 \%$ vitamin dan $86 \%$ air.
Berdasarkan Direktorat
Jenderal Hortikultura, (2018) produksi pisang tahun 2018 adalah sebanyak 72.642.792 kuintal dengan tanaman pisang sebanyak 81.289.450 pohon. Berdasarkan total hasil panen pisang tersebut maka dapat diperkirakan bahwa ketersediaan bonggol pisang juga sangat besar. Ketersediaan bonggol pisang akan mengikuti produksi pisang itu sendiri (Fawzia dkk., 2012). Oleh karena itu diperlukan upaya pemanfaatan bonggol pisang sebagai alternatif bahan makanan yang memiliki serat 
tinggi. Khususnya di daerah pusat produksi pisang, bonggol pisang dianggap sebagai bagian yang tidak bisa digunakan sehingga banyak yang dibuang (Fawzia dkk., 2012).

Salah satu pemanfaatan bonggol pisang adalah diolah menjadi produk makanan basah maupun kering, hal tersebut bertujuan untuk memperpanjang masa simpan, menambah nilai gizi dan nilai ekonomis serta menambah keanekaragaman pangan. Keanekaragaman pangan akan lebih menarik minat masyarakat terhadap bonggol pisang dibandingkan hanya dikukus, disayur ataupun digoreng. Contoh produk tersebut yaitu nugget dan kerupuk, nugget dan kerupuk merupakan makanan yang digemari oleh semua kalangan.

Nugget merupakan makanan siap saji yang banyak dikonsumsi masyarakat. Daya simpan nugget yang mampu bertahan cukup lama (disimpan dalam freezer) menjadi salah satu alasan makin meningkatnya konsumsi masyarakat terhadap nugget. Produk nugget yang beredar di pasaran terbuat dari daging sapi dan ayam yang harga jualnya mahal dan kurang menyehatkan. Biasanya produk yang terbuat dari bahan hewani mengandung tinggi lemak dan protein tetapi rendah serat. Bonggol pisang bisa menjadi alternatif yang tepat sebagai bahan baku pembuatan nugget karena berasal dari bahan nabati dan mempunyai serat yang tinggi.

Kerupuk adalah makanan kering yang terbuat dari bahan bahan yang mengandung pati tinggi, biasanya dikonsumsi sebagai pendamping makan Keunggulan dari kerupuk yaitu karena tahan lama dan tidak gampang busuk. Selama ini kerupuk yang ada dipasaran hanya tinggi kandungan karbohidrat saja, tetapi rendah serat dan protein (Koswara, 2009). Oleh karena itu bonggol pisang sebagai campuran dalam pembuatan kerupuk dapat menjadi upaya dalam memaksimalkan kandungan serat dalam kerupuk.

Banyaknya bonggol pisang yang dibuang cuma-cuma khususnya pada daerah tempat tinggal peneliti serta sedikitnya informasi mengenai macam olahan, pemanfaatan dan kandungan serat bonggol pisang. Maka peneliti tertarik untuk melakukan penelitian mengenai analisis kandungan serat nugget dan kerupuk dengan bahan dasar bonggol pisang kepok (Musa paradisiaca var. balbisina colla).

\section{METODE PENELITIAN}

Penelitian ini merupakan penelitian experimental design dengan dua produk dan tiga perbandingan formulasi. Formulasi nugget yaitu formula 1 (F1) dengan perbandingan antara bonggol pisang : tepung terigu ( $25 \%: 75 \%$ ), formula 2 (F2) $(50 \%: 50 \%)$, dan formula 3 (F3) (75\% : 25\%). Formulasi kerupuk yaitu formula 1 (F1) dengan perbandingan antara bonggol pisang: tepung tapioka (25\%: $75 \%$ ), formula 2 (F2) $(50 \%: 50 \%)$, dan formula 3 (F3) $(75 \%: 25 \%)$. Penelitian ini dilakukan selama 3 bulan dari bulan Juli - September 2020. Pembuatan formulasi nugget dan kerupuk dilakukan di Laboratorim Pangan Program Studi Gizi, Fakultas Ilmu Kesehatan, Universitas Ngudi Waluyo, Ungaran. Sedangkan Penelitian atau analisis kandungan serat dilakukan di Laboratorium BBTPPI (Balai Besar Teknologi Pencegahan Pencemaran Industri) Semarang. 
Alat yang digunakan dalam pembuatan nugget dan kerupuk bonggol pisang kepok adalah timbangan makanan, baskom, loyang, cobek, ulekan, parutan, blender, sendok, garpu, wajan, spatula, saringan, kukusan dan kompor. Bonggol pisang didapatkan dari kebun peneliti di Desa Pledokan, Kecamatan Sumowono, Kabupaten Semarang. Bahan lainnya yaitu tepung terigu protein sedang, tepung tapioka, tepung panir, minyak goreng, telur ayam, daging ayam, gula, garam, merica, ketumbar, kemiri dan bawang putih didapatkan dari warung dan swalayan. Uji analisis serat menggunakan metode gravimatri.

Penelitian dilakukan dengan beberapa tahapan yang meliputi proses menentukan formulasi nugget dan kerupuk bonggol pisang kepok dengan menentukan perbandingan antara bonggol pisang dan tepung terigu serta bonggol pisang dengan tepung tapioka. Tahapan selanjutnya adalah analisis kandungan serat pada masing masing formulasi sebanyak tiga kali pengulangan. Hasil analisis kandungan serat dianalisis secara deskriptif. Semua data diolah dengan menggunakan program Microsoft exel.

\section{HASIL DAN PEMBAHASAN Kandungan Serat Nugget Bonggol Pisang Kepok}

Uji kandungan serat pada penelitian ini dilakukan pada nugget yang sudah digoreng. Hasil analisis kandungan serat nugget bonggol pisang kepok dapat dilihat pada tabel 1 .

Tabel 1. Kandungan nilai serat pada nugget bonggol pisang kepok setiap 100 gram.

\begin{tabular}{ccccc}
\hline Formula & \multicolumn{3}{c}{ Ulangan } & Rata-rata \\
\cline { 2 - 4 } Nugget & 1 & 2 & 3 & \pm SD \\
\hline F1 & $0,189 \mathrm{~g}$ & $0,180 \mathrm{~g}$ & $0,189 \mathrm{~g}$ & $0,186 \mathrm{~g} \pm 0,0042$ \\
F2 & $0,329 \mathrm{~g}$ & $0,308 \mathrm{~g}$ & $0,329 \mathrm{~g}$ & $0,322 \mathrm{~g} \pm 0,0099$ \\
F3 & $0,518 \mathrm{~g}$ & $0,508 \mathrm{~g}$ & $0,516 \mathrm{~g}$ & $0,514 \mathrm{~g} \pm 0,0043$ \\
\hline
\end{tabular}

Berdasarkan Tabel 1. dapat dilihat hasil analisis kandungan serat, dari ketiga formulasi menunjukkan bahwa rata-rata kandungan serat nugget bonggol pisang kapok paling tinggi yaitu F3 sebanyak $0,51 \mathrm{~g}$, sedangkan kandungan serat nugget bonggol pisang kepok F2 sebanyak $0,322 \mathrm{~g}$, dan $\mathrm{F} 1$ sebanyak $0,186 \mathrm{~g}$. Standar deviasi dari data ini sebesar $0,0042-0,0099$. Hasil analisis deskriptif tersebut menunjukkan nilai standar deviasi yang lebih kecil daripada nilai rata-rata (mean), maka dapat dikatakan data bersifat homogen, yang berarti rata-rata analisis kandungan serat nugget bonggol pisang kepok mempunyai tingkat penyimpangan yang rendah.

\begin{abstract}
Formula 3 memiliki kandungan serat paling tinggi dikarenakan perlakuan dengan komposisi penambahan bonggol pisang paling banyak diantara yang lainnya yaitu sebanyak $75 \%$. Semakin tinggi penambahan bonggol pisang kepok pada nugget maka semakin tinggi pula kandungan serat yang terkandung dalam nugget serta dari proses pengolahan.
\end{abstract}

\section{Kandungan Serat Kerupuk Bonggol Pisang Kepok}

Uji kandungan serat pada penelitian ini dilakukan pada kerupuk yang sudah matang atau digoreng. Hasil analisis kandungan serat pada 
kerupuk bonggol pisang kepok dapat dilihat pada Tabel 2 .

Tabel 2. Kandungan nilai serat pada kerupuk bonggol pisang kepok setiap 100 gram

\begin{tabular}{ccccc}
\hline Formula & \multicolumn{3}{c}{ Ulangan } & Rata - rata \\
\cline { 2 - 4 } Kerupuk & 1 & 2 & 3 & \pm SD \\
\hline F1 & $0,729 \mathrm{~g}$ & $0,714 \mathrm{~g}$ & $0,737 \mathrm{~g}$ & $0,727 \mathrm{~g} \pm 0,009$ \\
$\mathrm{~F} 2$ & $0,778 \mathrm{~g}$ & $0,735 \mathrm{~g}$ & $0,728 \mathrm{~g}$ & $0,747 \mathrm{~g} \pm 0,022$ \\
$\mathrm{~F} 3$ & $0,894 \mathrm{~g}$ & $0,865 \mathrm{~g}$ & $0,824 \mathrm{~g}$ & $0,861 \mathrm{~g} \pm 0,029$ \\
\hline
\end{tabular}

Berdasarkan Tabel 2. dapat dilihat hasil analisis kandungan serat, dari ketiga formulasi menunjukkan bahwa rata-rata kandungan serat kerupuk bonggol pisang kapok paling tinggi yaitu kerupuk F3 sebanyak 0,861 g, sedangkan kandungan serat kerupuk bonggol pisang kepok F2 sebanyak $0,747 \mathrm{~g}$, dan yang paling rendah adalah F1 sebanyak $0,727 \mathrm{~g}$. Standar deviasi dari data ini sebesar $0,009-0,029$.

Hasil analisis deskriptif tersebut menunjukkan nilai standar deviasi yang lebih kecil daripada nilai rata-rata (mean), maka dapat dikatakan data bersifat homogen, yang berarti rata-rata analisis kandungan serat kerupuk bonggol pisang kepok mempunyai tingkat penyimpangan yang rendah. Formula 3 memiliki kandungan serat paling tinggi pada kerupuk dikarenakan memiliki komposisi bonggol pisang paling banyak diantara formula kerupuk lainnya yaitu $75 \%$. Perbedaan kadar serat tersebut juga akibat dari proses pengolahan.

Penelitian kali ini dilakukan analisis zat gizi serat untuk mengetahui kandungan serat yang terdapat pada nugget dan kerupuk bonggol pisang kepok. Bonggol pisang yang digunakan adalah bonggol pisang kepok yang sudah dipanen pisangnya. Metode pengolahan yang digunakan dalam pembuatan nugget bonggol pisang kepok adalah proses pengukusan dan penggorengan, sedangkan bahan tambahan yang digunakan adalah daging ayam dan bumbu dapur (merica, bawang putih, garam dan gula). Metode yang digunakan dalam pebolahan kerupuk bonggol pisang kepok meliputi pengukusan, penjemuran dan penggorengan. Bahan tambahan pangan berupa bumbu-bumbu dapur (ketumbar, bawang putih dan garam).

Mutu bonggol pisang yang paling bagus adalah bonggol pisang kepok yang sudah dipanen pisangnya dikarenakan kadar air rendah dan kandungan serat yang lebih tinggi dibandingkan dengan yang lainnya. Dari segi karakteristik bonggol pisang, pisang kepok mempunyai kandungan serat yang lebih tinggi dan kadar air yang lebih rendah dibandingkan dengan jenis pisang yang lainnya seperti pisang raja, mahuli, susu dan ambon. Serat yang terkandung pada bonggol pisang cukup tinggi. Bonggol pisang mentah dalam 100 gram mengandung serat sebanyak 9,9 gram (Aswandi dkk., 2013).

Bonggol pisang termasuk kategori bahan pangan yang mengandung tinggi serat. Serat yang terdapat dalam bonggol pisang sebagian besar terdiri atas karbohidrat antara lain selulosa, hemiselulosa, pektin dan lignin. Serat ini tidak dapat dihidrolisa oleh enzim pencernaan. 
Kandungan serat dalam 100 gram tepung terigu adalah sebanyak 0,3 gram, sedangkan kandungan serat untuk tepung tapioka dalam 100 gram adalah 0,9 gram (TKPI, 2017). Adanya bahan tambahan atau bahan pengikat selain bonggol pisang tersebut dapat menambah nilai serat yang terkandung didalamnya pula. Dilihat bahwa kandungan serat pada tepung tapioka lebih tinggi dari tepung terigu.

Bahan yang mengandung banyak serat akan mempercepat waktu transit sisa makanan di dalam usus sehingga menjadi lebih pendek (Luthfianto dkk, 2017). Makanan dengan kandungan serat kasar yang tinggi biasanya mengandung kalori, kadar gula dan lemak yang rendah sehingga dapat membantu mengurangi terjadinya obesitas (Santoso, 2011).

Sebelum diolah atau dalam keadaan mentah kandungan serat bonggol pisang cukup tinggi dan mengalami penurunan setelah diolah menjadi nugget dan kerupuk. Penurunan serat kasar diduga disebabkan oleh dinding sel selama proses pengolahan dan lama pengolahan menyebabkan turunnya kadar serat kasar, karena struktur gel pektin dan hemiselulosa rusak oleh pemanasan (Suprapto, 2004). Menurut Kusumawati dkk. (2012), kadar serat kasar tepung biji nangka mengalami penurunan setelah dilakukan blanching pada suhu $80^{\circ} \mathrm{C}$ selama 10 menit. Penurunan serat kasar dipengaruhi oleh suhu dan lama blanching.

Kandungan serat akan berbeda antara bahan pangan yang digunakan dan juga metode pengolahannya. Dari rata-rata hasil uji analisis serat pada 3 formula baik itu nugget atau kerupuk bonggol pisang kepok, didapatkan hasil bahwa yang mengandung serat tertinggi yaitu pada formula ke 3 . Hal itu dikarenkan proporsi bonggol pisang kepok yang lebih banyak dibanding dengan formulasi lainnya. Perbedaan bahan campuran yang digunakan juga berbeda. Nugget dibuat dengan perbandingan tepung terigu, sedangkan kerupuk dengan perbandingan tepung tapioka. Dari segi cara pengolahan untuk nugget lebih pendek prosesnya dibanding dengan kerupuk yang harus melalui proses pengeringan dengan cara dijemur di bawah sinar matahari sampai benar - benar kering.

Perbedaan yang mencolok tersebut menyebabkan kandungan serat pada kerupuk bonggol pisang kepok jauh lebih tinggi dibanding dengan kandungan serat pada nugget bonggol pisang kepok. Hal tersebut sesuai dengan penelitian Rahman dkk., (2015) bahwa kadar serat kasar menjadi semakin tinggi dengan suhu yang lebih panas. Pada penelitian tersebut menunjukkan bahwa bahan pangan yang direbus kandungan seratnya lebih tinggi dari bahan pangan yang dikukus.

Meningkatnya kadar serat kasar ini disebakan oleh dinding sel dari bahan terurai selama proses pengolahan dan lama pengeringan juga menyebakan peningkatan kadar serat pangan pada bahan pangan. (Suprapto, dalam Rahman dkk., 2015). Hal tersebut juga sejalan dengan pendapat Indradewi (2016) yang berpendapat bahwa semakin tinggi suhu yang digunakan, maka semakin rendah penurunan kadar serat. Sale pisang dengan pengeringan sinar matahari dan di dalam oven suhu $65^{\circ} \mathrm{C}$ pada malam hari dibandingkan pada suhu $45^{\circ} \mathrm{C}$ dan $55^{\circ} \mathrm{C}$. Keberadaan pektin juga menyebabkan terjadinya kenaikan 
kadar serat sale pisang yang dipanaskan pada suhu yang lebih tinggi. Menurut Bennet (dalam Indradewi, 2016) selama proses pemanasan, kandungan pektin meningkat sedangkan kandungan selulosa dan hemiselulosa menurun. Pembuatan nugget dan kerupuk juga diolah dengan cara digoreng dengan metode deep frying. Penggunaan minyak pada penggorengan kerupuk harus banyak agar kerupuk matang secara sempurna dan agar kerupuk yang dihasilkan renyah. Pada penelitian Susanty dkk. (2019) bahwa kadar serat abon udang yang diproses dengan metode pan frying memiliki kadar kadar serat lebih rendah dibandingkan metode deep frying.

Berdasarkan AKG 2019 serat bagi orang dewasa, baik perempuan ataupun laki-laki adalah 32 gram sampai 37 gram. Dari hasil diatas nugget bukan termasuk makanan yang tinggi serat dikarenakan dalam 100 gram hanya mengandung 0,514 gram dan 0,861 gram. Hal tersebut dikarenakan faktor pengolahan sehingga kadar serat pangan hilang dan kadar serat kasar menjadi turun.

Menurut

European

Commission, (2006) suatu bahan pangan dikatakan tinggi serat apabila dalam 100 gram bahan pangan terdapat $6 \mathrm{~g}$ serat atau $3 \mathrm{~g}$ serat per 100 kkal. Nugget hanya mengandung sekitar 0,186 gram - 0,514 gram dalam 100 gram nugget bonggol pisang kepok, atau hanya memenuhi $2,57 \%$ dari total kebutuhan serat minimal dan memenuhi $1,51 \%$ dari total kebutuhan serat orang dewasa. Sedangkan untuk kerupuk hanya mengandung sekitar 0,727 gram 0,861 gram dalam 100 gram kerupuk bonggol pisang kepok. Atau hanya memenuhi 4,3\% dari total kebutuhan serat minimal dan memenuhi $2,54 \%$ dari total kebutuhan serat orang dewasa. Persyaratan kerupuk ikan berdasarkan BSN (1992) yaitu kandungan serat kasar maksimal 1, maka kerupuk bonggol pisang sudah memenuhi syarat mutu dengan kandungan serat kasar tertinggi yaitu 0,861 gram.

\section{SIMPULAN}

Hasil penelitian disimpulkan bahwa kandungan rata-rata serat nugget bonggol pisang kepok yang tertinggi adalah F3 yaitu $0,514 \%, \mathrm{~F} 2$ yaitu $0,322 \%$, sedangkan $\mathrm{F} 1$ yaitu $0,186 \%$. Kandungan rata-rata serat kerupuk bonggol pisang kepok yang tertinggi adalah F3 yaitu $0,861 \%$, F2 yaitu $0,742 \%$, sedangkan F1 yaitu $0,727 \%$.

\section{DAFTAR PUSTAKA}

American Assosiation of Cereal Chemist (AACC). (2001). 'The Definition of Dietary Fiber'. Cereal Foods World, 46(3), 112-129.

Aswandi et al. (2013) 'Efek Complete Feed Bongol Berbagai Varietas Tanaman Pisang Terhadap $\mathrm{pH}$, NH3 dan VFA pada Kambing Kacang', Journal of Chemical Information and Modeling, 53(9), pp. 1689-1699. doi: 10.1017/CBO9781107415324. 004.

Badan Standarisasi Nasional. (1992). SNI 01-2713-1992. Kerupuk Ikan. Jakarta: Departemen Perindustrian Republik Indonesia.

BPOM. (2005). 'Ketentuan Pokok Pengawasan Pangan Fungsional', Peraturan Kepala Badan Pengawas Obat dan Makanan Republik Indonesia Nomor HK 00.05.52.0685, pp. $1-13$. 
Departemen Kesehatan R1. (2017). Tabel Komposisi Pangan Indo nesia. Departeman Kesehatan RI. Jakarta.

Direktorat Jenderal Hortikultura. (2020). Statistik Produksi. Luas Lahan dan Produktivitas Buah Pisang 2014-2020.

Kementerian Pertanian, Jakarta. European Commission (2006). 'Regulation (EC) No 1924/2006 of the European Parliament and the of the Council on nutrition and health claims made on foods', Official Journal of the European Union, (404), pp. 9-25.

Fawzia, F.N., Ulfia, M.,Marliando, M. (2012). 'Tepung Tempe dan Limbah Bonggol Pisang Sebagai Industri Rumahan'. Jurnal Kelitbangan vol. 01.

Indradewi (2016) 'Pengaruh Teknik Pengeringan Terhadap Kadar Gizi dan Mutu Organoleptik Sale Pisang ( Musa paradisiaca L .)', Fakultas Farmasi, Universitas Halu Oleo, 4(2), pp. 58-65.

Koswara, S. (2009). 'Pengolahan aneka kerupuk'. In Ebookpangan.com (p. 31).

Kusumawati, D. D., Amanto, B. S. and Muhammad, D. R. A. (2012) 'Pengaruh Perlakuan Pendahuluan Dan Suhu Pengeringan Terhadap Sifat Fisik, Kimia, dan Sensori Tepung Biji Nangka (Artocarpus heterophyllus)', Jurnal Teknosains Pangan Vol 2 No 2 April 2013, 1(1), pp. 4148.

Luthfianto, D., Noviyanti, R. D. and Kurniawati, I. (2017) 'Karakterisasi Kandungan Zat Gizi Bekatul pada Berbagai Varietas Beras di Surakarta', jurnal Kesehatan, 2(1), pp. 371-376. doi: 2407-9189.

Marsono Y. (2007). Prospek Pengembangan Makanan Fungsional. Makalah disampaikan pada Seminar Nasional dalam rangka National Food Technology Competation (NFTC).

Marsono, Y. (2004). Serat Pangan dalam Perspektif Ilmu Gizi. Pidato disampaikan dalam Pengukuhan Guru Besar. Majelis Guru Besar Universitas Gadjah Mada, Jogjakarta.

Maryanto, S dan Marsono, Y. (2019). The Atherogenic Index of Plasma Treated with Red Guava (Psidium guajava L.)'. IOP Conference Series: Earth and Environmental Science.

PERKENI. (2015). Pengelolaan dan Pencegahan Diabetes Melitus Tipe 2 di Indonesia.

Rahman, I. G., Sukmiwati, M. dan Dahlia (2015) 'Pengaruh Metoda Pemasakan Berbeda Terhadap Karakteristik Tepung Ikan Betok (Anabas testudineus)', 2(1), pp. 1-2.

Santoso, A. (2011). 'Serat Pangan (Dietary Fiber) dan Manfaatnya Bagi Kesehatan'. Jurnal Magistra No. 75 Th. XXIII. ISSN 0215- 9511.

Saragih, B. (2013). 'Analisis Mutu Tepung Bonggol Pisang dari Berbagai Varietas dan Umur Panen yang Berbeda'. Jurnal TIBBS Teknologi Industri Boga dan Busana ISSN 0216-7891 Vol. 9(1):22-29.

Satuhu, S. dan Supriyadi, A. (2008). Pisang, Budi Daya dan Prospek Pasar. Jakarta : Penebar Swadaya.

Suprapto. (2004). 'Pengaruh Lama 


\section{JGK-Vol.14, No.1 Januari 2022}

Blanching Terhadap Kualitas Stik Ubi Jalar

(Ipoema batatas L.) dari Tiga Varietas', Prosiding, pp. 220228.

Susanty, A., Yustini, P. E. and Nurlina, S. (2019) 'Pengaruh
Metode Penggorengan dan Konsentrasi Jamur Tiram Putih (Pleurotus streatus) Terhadap Karakteristik Kimia dan Mikrobiologi Abon Udang (Panaeus Indicus)', pp. 80-87. 